Article

\title{
The Social Impact of Digital Youth Work: What Are We Looking For?
}

\author{
Alicja Pawluczuk *, Gemma Webster and Colin Smith and Hazel Hall \\ Centre for Social Informatics, Edinburgh Napier University, Edinburgh, EH10 5DT, UK; E-Mails: a.pawluczuk@napier.ac.uk \\ (A.P.), g.webster@napier.ac.uk (G.W.), cf.smith@napier.ac.uk (C.S.), h.hall@napier.ac.uk (H.H.)
}

* Corresponding author

Submitted: 14 December 2018 | Accepted: 20 January 2019 | Published: 11 June 2019

\begin{abstract}
Digital youth work is an emerging field of research and practice which seeks to investigate and support youth-centred digital literacy initiatives. Whilst digital youth work projects have become prominent in Europe in recent years, it has also become increasingly difficult to examine, capture, and understand their social impact. Currently, there is limited understanding of and research on how to measure the social impact of collaborative digital literacy youth projects. This article presents empirical research which explores the ways digital youth workers perceive and evaluate the social impact of their work. Twenty semi-structured interviews were carried out in Scotland, United Kingdom, in 2017. All data were coded in NVivo 10 and analysed using thematic data analysis (Braun \& Clarke, 2006). Two problems were identified in this study: (1) limited critical engagement with the social impact evaluation process of digital youth work projects and its outcomes, and (2) lack of consistent definition of the evaluation process to measure the social impact/value of digital youth work. Results of the study are examined within a wider scholarly discourse on the evaluation of youth digital participation, digital literacy, and social impact. It is argued that to progressively work towards a deeper understanding of the social value (positive and negative) of digital youth engagement and their digital literacy needs, further research and youth worker evaluation training are required. Recommendations towards these future changes in practice are also addressed.
\end{abstract}

\section{Keywords}

adolescents; digital literacy; digital youth work; evaluation; social impact

\section{Issue}

This article is part of the issue "Critical Perspectives on Digital Literacies: Creating a Path Forward", edited by Hiller A. Spires (North Carolina State University, USA).

(C) 2019 by the authors; licensee Cogitatio (Lisbon, Portugal). This article is licensed under a Creative Commons Attribution 4.0 International License (CC BY).

\section{Introduction}

Digital technologies are no longer considered as merely supplementary educational tools. Rather, they comprise a deeply embedded element of youth work practices across Europe (Harvey, 2016). As youth workers aim to guide, empower, and support young people in their personal, social, and educational development (Sapin, 2013), digital media has been deployed to enhance communication, self-expression, and advocacy within and between youth projects (Black, Castro, \& Lin, 2015). Through video, photography, and digital storytelling, participatory youth-centred initiatives have provided young people with opportunities to claim their voices and to co-create works which reflect their lived experiences (Ito et al., 2015).

In the light of fast-paced digital advancements of the 21st century, youth-centred organisations report that measuring and interpreting the social impact of digital youth has become difficult (Wilson \& Grant, 2017). Whilst information on how to evaluate youth work outcomes and measure digital literacy are available, there is limited understanding of how to analyse and interpret the impact of digital youth projects (Mackrill \& Ebsen, 2017).

Digital literacy is defined here as the ability to use information technology for both information sharing and information creation practices. It is concerned with how 
young people access and engage with content as well as the "availability of content appropriate to the needs of users and opportunities to translate these activities into beneficial outcomes in everyday life" (Helsper, 2016). Digital literacy can be described as an evolving process, where young people access, navigate, examine, and produce digital media. Thus, the key competencies for digital literacy can be devised into three principles (Media Smarts, 2016): (1) use (skills such as technical know-how and the ability to use computer programs); (2) understand (skills related to critical thinking, contextualisation, and evaluation of digital media and its social impact); (3) create (skills related to digital media creation and effective online communication). In the context of this article, digital literacy youth projects are viewed as out-ofschool and youth-centred projects (young people meaning under the age of 26 years old), where digital media are utilised and/or examined and/or created.

Both scholars (Livingstone, Mascheroni, \& Staksrud, 2015; Mackrill \& Ebsen, 2017) and youth practitioners (Harvey, 2016; Wilson \& Grant, 2017) have advocated for further research into social impact evaluations of the interactions between young people and digital technologies. In an attempt to address this research gap, this article provides insights about youth workers' perceptions regarding social impact and attitudes towards social impact evaluations of digital youth work in Scotland, United Kingdom. Social impact is defined in this article as: "all social and cultural consequences to human populations of any public or private actions that alter the ways in which people live, work, play, relate to another, organise to meet their needs, and generally cope as members of society" (Burdge \& Vanclay, 1995, p. 59). The key questions addressed here are: (1) How do digital youth workers perceive and define the social impact of their work? and (2) What are youth workers' attitudes towards social impact evaluation of digital youth work? Data was collected through twenty interviews and the results of this study were analysed using thematic data analysis (Braun \& Clarke, 2006). Based on the data and literature review analysis, it is proposed here that current (externally governed) evaluation practices (for example, outcomesdriven surveys) limit digital youth workers' abilities to critically examine and provide feedback regarding the impact of digital youth work projects.

\section{Digital Youth Work: The Evolving Roles of Youth Workers}

In Europe, youth work is a broad term used to describe "out-of-school" informal learning initiatives aimed at young people's personal development, social integration, or active citizenship (European Commission, 2018). A youth worker's role is to support, enable, and empower young people to take active roles in shaping their society and their futures. Youth work related activities and project objectives vary from community arts to political activism. The role of the youth worker is often crucial when establishing "voluntary relationships with young people" (Sapin, 2013, p. 3) and assisting them as they transition into adulthood. Examples of youth work practice may vary in their form and goals. Examples of youth work activities include after-school art clubs, sports groups, multi-agency health clinics, and identityspecific groups (Sapin, 2013).

In recent years, young people's transition journeys into adulthood have become influenced by the emergence of digital technologies (Mills, 2016). Young people have been surrounded with novel digital tools to learn, communicate, and express themselves creatively (Black et al., 2015). Young citizens of the digital era, also described as "digital youth" (Erstad, 2012, p. 25), need the assistance of youth workers, who are continually exploring "new ways of using digital tools and technology" (Kiviniemi \& Touvimen, 2017, p. 9) with young people and for young people. Digital youth work evaluation has been identified as a key area for development by the European Commission's Digital Youth Work Experts group in 2018 (European Commission, 2018). Digital Youth Work Experts' recommendations state that:

As digital cultures and media are an intrinsic part of young people's lives, every youth worker should understand the importance of digital youth work and youth workers be able to address digital issues in their work. (European Commission, 2018, p. 12)

Youth work environments have the potential to address young people's digital literacy needs, which are often omitted at schools or at home (Harvey, 2016). Outsideof-school digital projects also provide young people with opportunities to explore new skills, to "enrich inquiry for underrepresented groups" (Black et al., 2015) and to deploy digital technologies as tools for self-expression and empowerment (Black et al., 2015).

Digital youth work, the term mostly used in Europe (Harvey, 2016; Kiviniemi \& Touvimen, 2017), is perceived as a vital part of youth engagement practices and defined as an area of youth work that implements digital technologies to enhance outcomes of youth centred initiatives (Harvey, 2017). Digital youth work's goals and ethics are the same as those proposed by traditional youth work (European Commission, 2018) and therefore should not be considered as a separate youth work method (Harvey, 2016). The central part of the practice is to focus on young people's self-development and voluntary participation (European Commission, 2018). Digital youth work might involve either offline or online engagement; digital technologies can be used as "either a tool, an activity or a content in youth work" (European Commission, 2018). Digital youth workers might be employed on a voluntary or paid basis, and may be experts from various backgrounds (for example: arts, digital technologies, or youth work). Examples of digital youth-work may include coding clubs (CoderJojo Scoltand, 2018), participatory media clubs (Sawhney, 2009), digital campaigning 
and storytelling projects (Stornaiuolo \& Thomas, 2017), or online chat support (LGBT Youth Scotland, 2018).

As digital literacy and creativity are emphasised as key 21st century skills (van Laar, van Deursen, van Dijk, \& de Haan, 2017) new streams of funding have become available for youth work organisations to implement digital technologies in their practice (for example Hyder, 2016; Wilson \& Grant, 2017). Whilst external funds enable digital literacy and digital inclusion projects' facilitation and innovative youth work solutions, it also creates a specific set of challenges. Firstly, youth workers' new and multi-layered roles of nurturing societyyouth/youth-technology relationships is critical and requires "an agile mind-set, being willing to try new things and learn from both success and failure, and [need to] be supported to do so" (European Commission, 2018, p. 7). For young participants to benefit from their experience, youth workers need to create an environment which enables critical information sharing, collaboration, interest-driven learning, and self-expression (Ito et al., 2013). Secondly, the management and evaluation of digital youth work projects must be considered. Whilst there have been many successful examples of European digital youth-work projects (Harvey, 2016), there has also been evidence of scepticism, "tech-fears", and digital-literacy insecurities among those who facilitate and engage with them (Pawluczuk, Hall, Webster, \& Smith, 2018). There are currently limited resources to provide youth workers with sufficient digital training (Harvey, 2016), project management, and evaluation resources (European Commission, 2018; Wilson \& Grant, 2018).

\section{Measuring the Social Impact of Digital Youth Work: What Are We Looking For?}

Discussion of the social value of the digital technologies in young people's lives has been examined by both scholars (Livingstone \& Sefton-Green, 2016; Mills, 2016) and youth work practitioners (Harvey, 2016; Wilson \& Grant, 2017). The impact data have not only been collected through various disciplinary and methodological lenses (Black et al., 2015; Fawcett, Fisher, Bishop, \& Magassa, 2013; Koh, 2013) but has emphasised different aspects of technology used by young people, such as communication (Buccieri \& Molleson, 2015), informal learning (Erstad, 2012), information behaviour (Koh, 2013), identity development (Boyd, 2014), and online safety (Ashktorab \& Vitak, 2016). Externally funded youth projects and organisations are required to collect and analyse data to prove that their work is having a positive impact to continue receive future funding. In the context of the traditional/non-digital youth work projects, youth participation (Cooper, 2018) and youth empowerment frameworks (Walker, 2007) have been proposed as effective tools to analyse the value of the projects. However, in recent years, dynamic and multifaced digital youth-centred initiatives have become increasingly difficult to evaluate. Currently, it is unclear as to what counts as evidence of positive impact of digital youth work projects (Wilson \& Grant, 2017). The uncertainty linked to the definition of impact of digital youth projects has been highlighted by youth workers in the United Kingdom:

What is the threshold for a young person to be classed as digitally literate? What does success look like and once again is this the correct aspiration? Are digital skills an outcome in themselves or purely a means to an end, a process by which to gain other skills or qualities and ultimately, long-term improvements in wellbeing? (Wilson \& Grant, 2017, p. 57)

To analyse and evaluate the digital skills essential in the 21st century, scholars propose theoretical frameworks examining media and information literacy (Wilson, 2012), basic digital skills (Van Deursen, Helsper, \& Eynon, 2014), digital competency (Lang, Shang, \& Vragov, 2009), digital literacy (Reynolds, 2016), and digital citizenship (Collier, 2016).

However, the terms digital skills and digital literacy change meaning according to learning context or geographical location. In 2017, G20 policy makers (a group of finance ministers and central bank governors from 19 of the world's largest economies and the European Union) argued that it is essential not to introduce a universal indicator to measure digital literacy, but instead implement a "standardized, multidimensional [set of measures] of digital literacy" (Chetty et al., 2018).

The uncertainty surrounding the value of digital literacy is also noted in the digital youth work context. While basic digital skills are continuously developing, it has become increasingly challenging to classify a young person as a "digital literate" (Wilson \& Grant, p. 57). Basic digital skills framework is designed to primarily "capture the more tangible and objective quantitative elements of digital skills development", and thus, does not provide other elements of youth development journey. Moreover, as outcomes of media-rich informal learning environments are often "rich in contributions to social and emotional development, to identity and motivation, to developing skills of collaboration and mutual support", the analysis of their social value might require use of complementary and long-term approaches to evaluation (Lemke, Lecusay, Cole, \& Michalchik, 2015, p. 5).

\section{Methodology}

The Qualitative data was collected from twenty semistructured interviews and a focus group with digital youth work practitioners based in the United Kingdom and conducted in mid-2017. The purpose of the interviews and the focus group was to elicit, and gain a deeper understanding of, youth digital workers' perceptions of their practices, and to examine the social impact evaluation methods used to measure its impact. Two key questions guided the structure of the data collection: How do 
youth digital workers define and measure the social impact of their work? And what are their attitudes towards social impact evaluations of digital youth work?

\subsection{Study Participants}

The research participants were primarily recruited through the Scottish Digital Youth Work Network. The aim of the Scottish Digital Youth Work network is to connect those practitioners who use digital tools and online spaces in their work with young people and to exchange and develop good practice models, both in Scotland and internationally (Youth Link Scotland, 2017). Information about the study was also shared online and via social media. Whilst the majority the interviews took place face-toface, two were facilitated via Skype. Nineteen of the research subjects were based in Scotland and one worked in England. Gender distribution was 60 percent males and 40 percent females. While all the interviewees were aged 25 years and older, nearly half (9) of the participants were aged between 35 and 44 . Other age groups participating in the interviews were as follows: six participants aged $25-34$, four participants aged $35-44$, and one in the 55-64 age bracket. In the reporting data, all participants have been anonymised. Due to the small sample size and its geographical location (Scotland, United Kingdom), caution must be applied, as findings might not be transferable to other countries.

At the time of the study, most of the participants (16) had five or more years of experience with implementing digital technologies in youth work. Among the most experienced participants were those with over 10 years of knowledge of the use of digital technologies in the youth engagement context. Only four of the practitioners interviewed had begun to implement digital technologies into their youth engagement work within the last five years. The typology of digital activities associated with interviews is illustrated in Table 1. Digital Storytelling defined here as "employment of story and digital technologies for personal expression" (Alrutz, 2015, p. 2) was a predominant theme in the interviews. Fifteen participants defined their projects as digital storytelling projects. The second most common digital youth activities among participants included Digital Arts (graphic design, animation, sound design) and Media Production (video, film production). The least declared types included two game design

Table 1. Study participant's subset data and digital youth projects categories, as coded by the authors of this article.

\begin{tabular}{|c|c|c|c|c|c|c|c|c|}
\hline \multirow[t]{2}{*}{ Name } & \multirow{2}{*}{$\begin{array}{l}\text { Years of experience of } \\
\text { using digital technologies } \\
\text { in youth projects }\end{array}$} & \multicolumn{7}{|c|}{ Types of digital youth projects } \\
\hline & & $\begin{array}{l}\text { Digital } \\
\text { Arts }\end{array}$ & $\begin{array}{l}\text { Digital } \\
\text { Storytelling }\end{array}$ & $\begin{array}{l}\text { Media } \\
\text { Production }\end{array}$ & $\begin{array}{l}\text { Social } \\
\text { Media }\end{array}$ & Coding & $\begin{array}{l}\text { Game } \\
\text { Design }\end{array}$ & $\begin{array}{l}\text { Digital } \\
\text { Literacy }\end{array}$ \\
\hline Alex & $5-10$ & $\checkmark$ & & & & & & \\
\hline Alison & $0-5$ & & $\checkmark$ & $\checkmark$ & & & & \\
\hline Andy & $0-5$ & & $\checkmark$ & & $\checkmark$ & & & \\
\hline Blake & $10+$ & $\checkmark$ & $\checkmark$ & & $\checkmark$ & $\checkmark$ & $\checkmark$ & \\
\hline Carla & $5-10$ & & & & $\checkmark$ & & & \\
\hline Chris & $5-10$ & $\checkmark$ & & & & $\checkmark$ & & \\
\hline Debbie & $10+$ & $\checkmark$ & $\checkmark$ & & $\checkmark$ & $\checkmark$ & $\checkmark$ & $\checkmark$ \\
\hline Gabriel & $10+$ & $\checkmark$ & & $\checkmark$ & & $\checkmark$ & & \\
\hline Jamie & $5-10$ & & $\checkmark$ & & & & & $\checkmark$ \\
\hline Jo & $10+$ & & $\checkmark$ & $\checkmark$ & & & & \\
\hline Janek & $5-10$ & & $\checkmark$ & $\checkmark$ & & & & \\
\hline Karel & $5-10$ & $\checkmark$ & $\checkmark$ & & & & & \\
\hline Kyle & $0-5$ & & $\checkmark$ & $\checkmark$ & & & & \\
\hline Martin & $5-10$ & $\checkmark$ & & & & & & \\
\hline Marta & $10+$ & & & & & & & $\checkmark$ \\
\hline Max & $10+$ & & $\checkmark$ & $\checkmark$ & & & & \\
\hline Rowan & $5-10$ & & $\checkmark$ & $\checkmark$ & & & & \\
\hline Ryan & $0-5$ & & $\checkmark$ & & & $\checkmark$ & & \\
\hline Sam & $5-10$ & & $\checkmark$ & $\checkmark$ & & & & \\
\hline Sandy & $5-10$ & & $\checkmark$ & & $\checkmark$ & & & \\
\hline
\end{tabular}


projects and three digital literacy projects. Digital youth workers' roles varied from direct digital learning delivery (the use of digital video, animation or sound design in youth-centred contexts) to overseeing digital literacy projects delivery (where young people's understanding of digital media is explored).

\section{Data Analysis}

\subsection{Narrative 1: Emphasising the Positive Social Impacts of Digital Youth Work}

Digital youth workers were invited to share their perceptions and definitions of the social impact of digital youth work initiatives. An on-going narrative focused on empowerment, engagement, and learning emerged from all twenty conversations. Whilst discussing the importance of their work, many of the digital youth workers repeatedly referred to so-called "soft skills" - such as confidence and a sense of pride-as indicators of project success. Alex noted that, "confidence is one that we quite often associate with the arts, and [becoming] confident to express yourself". Digital youth projects were also described as enhancing social skills and facilitating relationship-building. Chris stated that:

I'll only see people for a few hours, and what's been really lovely to see is a combination of instant relationships, that happen through the fact that they all know Minecraft, and they get chatting really quickly.

Digital youth workers believed that these technological developments have had a mainly positive impact on social inclusion, youth work related power dynamics, and participation amongst young people. Sam indicated that digital technologies provide opportunities for equal dialogue and enhanced collaboration with young participants: "Digital lets us change the way we work with young people, but also changes the amount of influence...young people have over us".

Despite this agreement that social impact is primarily positive, some argued that there is a problematic tendency in the field to focus solely on positive results during the evaluation process. Fifteen out of twenty digital youth workers believed that social impact evaluation is mainly concerned with "giving the funders what they want" (Carla). Thus, if "funders want to see the positive outcome" (Chris), it is a common practice to overemphasise, or even fabricate, a project's positive impact evidence. Gabriel added that, "If you build your evaluation around improved self-worth then there's at least an unconscious impulse to not record when a young person is disappearing down a hole."

To successfully apply, receive, and justify funding, youth work organisations in the United Kingdom are required to either propose a set of project outcomes or adopt existing ones from a funding body. This is often viewed as a technocratic and overly controlling approach to social impact analysis and was repeatedly referred to as a source of frustration:

You apply for some funding and that funding has certain things you have to achieve in it so you then tailor your project to meet those needs. You hope that it's about meeting the individual needs and being flexible to the young people that you end up working with but ultimately you have to then match the goals that you've said you would reach which is always a little bit frustrating. (Chris)

This problematic relationship with the project funders with regards to social impact evaluation was consistently highlighted across all interviews.

\subsection{Narrative 2: The Digital Element of Youth Work}

The results also provided evidence that the definition of the term "digital" varies significantly in the digital youth sector. As the use of technology is an expectation in youth work, some youth projects tick "the digital box" without providing young people with a meaningful experience. For example, Carla indicated that:

A lot of youth projects just maybe provide an X-box or a computer and let the young people loose on it. They wouldn't really be doing any dedicated work to develop the young peoples' skills on it, but they sort of feel they've ticked a digital box because they've just got an X-box sitting in the corner.

Carla additionally suggested that often digital technologies are solely used for communication between workers and young people, and therefore might not be adding "anything innovative and exciting" to projects. Whilst funding for digital youth participation has become more common in the United Kingdom, many projects are thought to add "digital elements" that aren't valueadded to their applications. Rowan, for example, described the "the digital bit" as a poorly defined element among digital youth workers. He complained that the digital element is often treated as "a marginalised lump rather than this thing that kind of goes in between everything we do." Further, he discussed the lack of context for many of the digital youth initiatives: "I just got that impression that [youth organisations] bought kit-they got some kit-and they'll give you some random training."

\subsection{Narrative 3: Social Impact of Digital Youth Work Can Be Seen, But It Is Hard to Evidence}

Digital youth workers described social impact evaluation as a form of transformation, which they personally witness. Alison claimed that, in her work, it is about "being able to see it [social impact] as opposed to evaluate it". These notions of feeling, or sensing, social impact during youth digital projects were highlighted by most of the 
participants. Due to the dynamic nature of this transformation, it was indicated that the formal process of impact assessment-where data is collected and sharedis an ineffective means of evaluation. Social impact evaluation was also perceived as "boring", or the final-and least exciting - part of youth projects. Study participants complained about the use of traditional project feedback surveys, "because kids don't want to fill out forms, [and] workers don't want to fill out forms with kids. So, you know, you think 'who are we really doing this for?'”

The results of this study indicate that social impact assessment is a time-consuming process, and for it to be facilitated effectively, more time needs to be allocated to assessment, both during the project as well as after its completion. Rowan stated that, "If you are a tutor on your own and you are meant to be just teaching digital media or performance, or whatever, you're like oh that's half of your workshop gone, you know". The time pressures in addition to the under-staffed nature of the evaluation process were further discussed by Chris:

I'm Project Co-ordinator as well as running the workshops and I'm doing the evaluation. The people who commissioned me to do it are basically saying well you're going to be there anyway so you might as well do all those things. I'm like yes, but I can't lead a workshop and take millions of photographs and spend twenty minutes signing people in and logging all their information, and the data that you need and capturing their feedback and actually getting some valuable delivery out of it.

Finally, fifteen out of twenty youth workers asserted that social impact evaluation should be primarily perceived as a learning process. It was agreed that the purpose of social impact assessment is to know if they provided a worthwhile experience for the participants, and to learn whether-and in what ways - their current digital youth practice could improve. However, it was also believed that due to the funders' expectations and tight deadlines, the evaluation process is frequently underused, at least in the context of organisational or youth learning. Blake complained that, "I filled in a smiley face to a frowny face it normally goes somewhere and it gets correlated and I don't ever hear back about it." Too often, organisations are forced to deliver "cookie cutter kind of programmes and make everyone fit into them" (Alison). Blake indicated that funders are too detached from youth projects to be able to fully comprehend the project's progress, and, consequently, its social impact. The conflict of interests between funders and workers creates problems relating to inconsistent understandings and perceptions of what matters during the evaluation, both for youth practitioners and young people. Jane admitted that, "it's not very often that an obvious benefit or gain for the young person while being part of an evaluation. And I don't think anybody's really got that cracked yet. Because I think that's probably the hardest bit of youth participation."

\section{Discussion}

Digital youth workers struggle to define and evaluate the digital element of their youth work practice and are under pressure to provide primarily positive evaluation results of their projects. Two distinctive themes were identified in this study: (1) limited critical engagement with the social impact evaluation process of digital youth work projects and its outcomes, and (2) lack of consistent definition of the evaluation process to measure the social of digital youth work.

\subsection{Limited Critical Engagement with the Social Impact Evaluation Process of Digital Youth Work Projects and Its Outcomes}

In alignment with existing research (Mackrill \& Ebsen, 2017; Wilson \& Grant, 2017), this study indicates that youth workers have limited opportunities to critically engage with the social impact evaluation of digital youth. Social impact evaluation is viewed as a time consuming administrative process (Bossen, Dindler, \& Iversen, 2016), which primarily serves to fulfil digital youth work funding criteria. Youth workers are aware of and consider the following theoretical concepts in their work: digital literacy (Covello, 2010), basic digital skills (Mcgillivray, Jenkins, \& Mamattah, 2017), and digital competency (Gutiérrez \& Tyner, 2012). However, they also argue that practical implications of such theoretical concepts have limitations (Harvey, 2016; Wilson \& Grant, 2017). It is thus apparent that "standard methods of digital skills measurement are not always appropriate and may not capture the varied types of [young people's] progression" (Wilson \& Grant, 2018, p. 4). The results of this article also indicate that compulsory application of pre-agreed outcomes, technocratic formats, or frameworks in digital youth work evaluation might lead to fabricated evaluation results. Likewise, existing scholarly analysis on youth workers' practices in the United Kingdom shows that digital youth workers view social impact evaluation primarily as a process to sustain organisational funding. St Croix defines the above problem as "[youth work evaluation] impact regimes" where "competition between providers [of youth work] for an ever-diminishing funding pot means that everybody must be an impact enthusiast" (2018, p. 431). It can thus be suggested that the lack of critical engagement with evaluation and measuring "only what they [digital youth workers] would like to be there" (Merli, 2002, p. 115), may result in limited (if not false) interpretations and understandings of young people's digital literacy needs, aspirations, and their associated social impacts. Scholars emphasise that a lack of young people's meaningful participation or/and critical engagement in youth-centred project design and its evaluation is both unethical and disempowering (for example Checkoway \& Richards-Schuster, 2005; Cooper, 2018; Gawler, 2005). Cooper states that an evaluation makes little sense unless it is understood as part of a learning 
process" (2018, p. 102). Gawler argues that "if the information gathering will not directly benefit the children and adolescent involved or their community the evaluation process should not proceed" (2005, p. 3).

\subsection{Lack of Consistent Definition of the Evaluation Process to Measure the Social of Digital Youth Work}

The results of this study correlate with previous ones which assert that examining the social value of the latest digital developments has become increasingly difficult, both for researchers (Mackrill \& Ebsen, 2017) and youth workers (Kiviniemi \& Tuominen, 2017). It is evident that traditional youth work, defined as a fast-changing practice of "continuous analysis, choice, judgment decision making" (Batsleer \& Davies, 2010, p. 5), has become more complex due to the expansions and impressiveness of the digital age. Subsequently, workers struggle to define and articulate the possible social impacts of the digital side of their youth projects (Wilson \& Grant, 2017).

The lack of a consistent definition of the evaluation process for measuring the social of digital youth work presented here was also documented by Wilson and Grant:

What is the threshold for a young person to be classed as digitally literate? What does success look like and once again is this the correct aspiration? Are digital skills an outcome in themselves or purely a means to an end, a process by which to gain other skills or qualities and ultimately, long-term improvements in wellbeing? (2017, p. 57)

Current findings support the idea of "standardized, multidimensional [set of measures] of digital literacy" (Chetty et al., 2018) to improve the analysis of digital literacy projects. However, it is also evident that the interactive, multi-layered, and unpredictable nature of digital youth projects often leave project facilitators unable to decide which youth developmental contexts of their work should be evaluated (Lemke et al., 2015).

\section{Recommendations}

To address the digital literacy needs of the 21st century, it is essential to gain a critical and holistic understanding of young people's digital literacy needs. Digital youth work environments offer young people environments where both their personal development and digital literacy can be explored. The outcomes of digital youth work projects could provide youth workers, researchers, and policy makers with important findings about young people's digital needs and aspirations. However, youth workers need to be provided with appropriate support, training, and tools for social impact evaluation of digital youth work (Harvey, 2016).

At present, more research is needed to understand both the social impact of digital youth work and its as- sessment. To analyse the vast range of social impacts that can occur during digital youth work projects, researchers should look beyond their disciplines to facilitate cross-disciplinary solutions and analysis of the multimodal human experience of digital projects participation. Although creative and participatory tools are currently available to measure youth development (Flores, 2007), social impact (McCabe \& Horsley, 2008), and digital skills (Mcgillivray et al., 2017), there is a need for further research linking these to problematic areas in order to provide digital youth practitioners with guidance and a set of practical assessment tools. Examples of digital tools and applications (such as the use of video recordings documentation and digital games performance-based assessment) have already been tested in an informal education setting (Lemke et al., 2015); thus an up-to-date comparative analysis of such studies and their effectiveness would be beneficial for further research in this area.

To improve the quality of social impact and its evaluation of digital youth work, a review of currently used methods should be carried out. An analysis of digital youth work funder's evaluation criteria in relation to the previously documented phenomena of "target culture" in youth work in the United Kingdom (Cooper, 2018 , p. 42) could also provide useful insights. Furthermore, a study of the existing power dynamics between digital youth workers, and their impact on the validity of the evaluation outcomes, could result in vital contributions to both research and digital youth work practice applications.

The importance of youth participation in the design and social impact evaluation should not be underestimated in the context of digital literacy youth projects. Participatory youth-centred approaches to digital literacy projects design and its assessment may not only provide reliable evaluation data, but may reveal unique insights about young people's digital literacy needs and aspirations (Pawluczuk et al., 2018).

The analysis presented in this article suggests that digital youth workers should be provided with a degree of flexibility and freedom when analysing the social impact of their work. Funding organisations ought to "move beyond narrowly conceived ideas of performance measurement and target setting" (Belfiore \& Bennett, 2007, p. 32). As Thomas and Percy-Smith argue, youth project workers should be encouraged not merely to examine their "success and failure", nor to ask whether or not a project "got participation right", but to think reflectively about the journey and the process (Percy-Smith \& Thomas, 2009, p. 32). To understand the impact of digital youth work, it is essential not to "romanticize" the emancipating qualities of the digital world (Buckingham, 2008), but to encourage social impact evaluation as a critical process, encompassing positive and negative outcomes and associated challenges.

Finally, it is vital to note that the roles of digital youth workers have yet been largely unexamined by scholarly literature. More research is required to understand 
this emerging field of research and youth work practice. As stated by Kiilakoskl, "to define who we are [as digital youth workers], what we do and why we do it has never before more critical" (2017, p. 19). Thus, research collaborations to further examine social impact evaluation of digital youth might consider examining multiplestakeholders' perspectives, including young people, digital youth workers, funding organisations, policy makers, and researchers.

\section{Conclusion}

This article presents empirical research examining youth workers' perceptions and experiences of social impact evaluation of digital youth work in the United Kingdom. Through thematic analysis (Braun \& Clarke, 2006) of twenty semi-structured interviews, two problems were identified: (1) limited critical engagement with the social impact evaluation process of digital youth work projects and its outcomes, and (2) lack of consistent definition of the evaluation process to measure the value of digital youth work. Results of the study were examined within a wider scholarly discourse including the evaluation of youth digital participation, digital literacy, and social impact. The evidence presented here suggests that further research and youth worker evaluation training are required to obtain a holistic understanding of understanding of the social impact (positive and negative) of digital youth engagement and young people's digital needs. The analysis presented here adds to the growing body of literature on digital youth (Black et al., 2015), digital youth evaluation (Lemke et al., 2015), and digital literacy measurement (Covello, 2010; Helsper, 2016). Finally, this study sheds light on the importance of the emerging roles of digital youth workers and may provide basis for future scholarly investigations in this area.

\section{Acknowledgments}

This research was funded by Edinburgh Napier University. We thank our research participants and the members of the Scottish Digital Youth Work Network for their support during the study.

\section{Conflict of Interests}

The authors declare no conflict of interests.

\section{References}

Alrutz, M. (2015). Digital storytelling and youth: Toward critically engaged praxis. Youth Theatre Journal, 29(1), 1-14. http://doi.org/10.1080/08929092.2015. 1020184

Ashktorab, Z., \& Vitak, J. (2016). Designing cyberbullying mitigation and prevention solutions through participatory design with teenagers. In Proceedings of the $2016 \mathrm{CHI}$ conference on human factors in com- puting systems (pp. 3895-3905). New York, NY: ACM. http://doi.org/10.1145/2858036.2858548

Batsleer, J., \& Davies, B. (2010). What is youth work? Empowering youth and community work practice. http://doi.org/10.1093/cdj/bsr050

Belfiore, E., \& Bennett, O. (2007). Rethinking the social impacts of the arts. International Journal of Cultural Policy, 13(2), 135-151. http://doi.org/10.1080/ 10286630701342741

Black, J., Castro, J. C., \& Lin, C.-C. (2015). Youth practices in digital arts and new media: Learning in formal and informal settings. http://doi.org/10.1057/ 9781137475176

Bossen, C., Dindler, C., \& Iversen, O. S. (2016). Evaluation in participatory design: A literature survey. In Proceedings of the 14th Participatory Design Conference (pp. 151-160). New York, NY: ACM. http://doi.org/ 10.1145/2940299.2940303

Boyd, D. (2014). It's complicated: The social lives of networked teens. Clinical Social Work Journal, 43(2), 249-250. http://doi.org/10.1007/s10615-014-0512-3

Braun, V., \& Clarke, V. (2006). Using thematic analysis in psychology. Qualitative Research in Psychology, 3(2), 77-101. http://doi.org/10.1191/1478088706qp063 oa

Buccieri, K., \& Molleson, G. (2015). Empowering homeless youth: Building capacity through the development of mobile technology. Journal of Community Practice, 23(2), 238-254. http://doi.org/10.1080/ 10705422.2015.1027802

Buckingham, D. (Ed.). (2008). Youth, identity, and digital media. Cambridge and London: The MIT Press.

Burdge, R. J., \& Vanclay, F. (1995). Social impact assessment. Environmental and Social Impact Assessment, 31-65. https://doi.org/10.1080/07349165. 1996.9725886

Checkoway, B., \& Richards-Schuster, K. (2005). Participatory evaluation with young people. Ann Arbor, MI: University of Michigan.

Chetty, K., Liu, Q., Nozibele, G., Jaya, J., Li, W., \& Chen, F. (2018). Bridging the digital divide: Measuring digital literacy Economics. Economics, 12. http://dx.doi.org/ 10.5018/economics-ejournal.ja.2018-23

CoderJojo Scoltand. (2018). CoderDojo Scotland. Retrieved from http://coderdojoscotland.com/clubs

Collier, A. (2016). The heart of digital citizenship / Anne Collier / TEDxGeneva. Retrieved from https://www. youtube.com/watch?v=Uww2XHnijKw

Cooper, S. (2018). Participatory evaluation in youth and community work. Oxon: Routledge.

Covello, S. (2010). A review of digital literacy assessment instruments. Retrieved from https://www. academia.edu/7935447/A_Review_of_Digital_ Literacy_Assessment_Instruments

Erstad, O. (2012). The learning lives of digital youthBeyond the formal and informal. Oxford Review of Education, 38(1), 25-43.

European Commission. (2018). Developing digital youth 
work Policy recommendations, training needs and good practice examples. Brussels: European Commission. Retrieved from http://uni-sz.bg/truni11/wpcontent/uploads/biblioteka/file/TUNI10042667.pdf

Fawcett, P., Fisher, K. E., Bishop, A. P., \& Magassa, L. (2013). Using design thinking to empower ethnic minority immigrant youth in their roles as technology and information mediaries. In $\mathrm{CHI}$ '13 extended abstracts on human factors in computing systems (p. 361). http://doi.org/10.1145/2468356.2468420

Flores, K. S. (2007). Youth participatory evaluation: Strategies for engaging young people. San Francisco, CA: John Wiley \& Sons.

Gawler, M. (2005). Useful tools for engaging young people in participatory evaluation. Geneva: UNICEF CEE/CIS Regional Office. Retrieved from http://betterevaluation.org/resources/overview/ tools_engaging_young_people_particip_eval

Gutiérrez, A., \& Tyner, K. (2012). Media education, media literacy and digital competence. Comunicar. http:// doi.org/10.3916/C38-2012-02-03

Harvey, C. (2016). Using ICT, digital and social media in youth work. National Youth Council of Ireland 2016. Dublin: National Youth Council of Ireland.

Helsper, E. (2016). Inequalities in digital literacy: Definitions, measurements, explanations and policy implications. In Survey on the useHyder, N. (2016). Evaluation of TTS.Digital To inspire digital creativity in young people. Glasgow. Retrieved from https://www.creativescotland.com/resources/ professional-resources/research/creative-scotlandresearch/evaluation-of-tts-digita

Ito, M., Gutiérrez, K., Livingstone, S., Penuel, B., Rhodes, J., Salen, K., ... Watkins, S. C. (2013). Connected learning: An agenda for research and design. Irvine, CA: Digital Media and Learning Research Hub.

Ito, M., Soep, E., Kligler-vilenchik, N., Shresthova, S., Gamber-Thompson, L., \& Zimmerman, A. (2015). Learning connected civics: Narratives, practices, infrastructures. Curriculum Inquiry, 45(1), 10-29. http://doi.org/10.1080/03626784.2014.995063

Kiilakoskl, T. (2017). The pillars of digital youth work. In J. Kiviniemi \& S. Tuominen (Eds.), Digital youth work-The Finish perspective (pp. 19-28). Helsinki: Verke. Retrieved from https://www.verke.org/wpcontent/uploads/2017/11/Digital-youth-work-aFinnish-perspective_web.pdf

Kiviniemi, J., \& Tuominen, S. (Eds.). (2017). Digital youth work-The Finish perspective. Helsinki: Verke. Retrieved from https://www.verke.org/wp-content/ uploads/2017/11/Digital-youth-work-a-Finnishperspective_web.pdf

Koh, K. (2013). Adolescents' information-creating behavior embedded in digital Media practice using scratch. Journal of the Association for Information Science and Technology, 64(9), 1826-1841.

Lang, K. R., Shang, R. D., \& Vragov, R. (2009). Designing markets for co-production of digital culture goods.
Decision Support Systems. http://doi.org/10.1016/j. dss.2009.05.010

Lemke, J., Lecusay, R., Cole, M., \& Michalchik, V. (2015). Documenting and assessing learning in informal and media-rich environments. Cambridge, MA: MIT Press.

LGBT Youth Scotland. (2018). LGBT Youth scotland digital support. Retrieved from https://www.Igbtyouth.org. uk/groups-and-support/digital-support

Livingstone, S., Mascheroni, G., \& Staksrud, E. (2015). Developing a framework for researching children's online risks and opportunities in Europe. EU Kids Online. Retrieved from https://www.eukidsonline.net

Livingstone, S., \& Sefton-Green, J. (2016). The class: Living and learning in the digital age. New York, NY: NYU Press.

Mackrill, T., \& Ebsen, F. (2017). Key misconceptions when assessing digital technology for municipal youth social work. European Journal of Social Work, 1-12. https://doi.org/10.1080/13691457.2017.1326 878

McCabe, A., \& Horsley, K. (2008). The evaluator's cookbook: Exercises for participatory evaluation with children and young people. London and New York: Routledge.

Mcgillivray, D., Jenkins, N., \& Mamattah, S. (2017). Rapid review of evidence for basic digital skills. Edinburgh: Scotland's Digital Participation Charter. Retrieved from https://digitalparticipation.scot/resources/ reports

Media Smarts. (2016). Digital literacy fundamentals. Retrieved from https://mediasmarts.ca/digital-medialiteracy/general-information/digital-media-literacyfundamentals/digital-literacy-fundamentals

Merli, P. (2002). Evaluating the social impact of participation in arts activities. International Journal of Cultural Policy, 8(1), 107-118. http://doi.org/10.1080/ 10286630290032477

Mills, K. L. (2016). Possible effects of internet use on cognitive development in adolescence. Media and Communication, 4(3), 4-12. http://doi.org/10.17645/ mac.v4i3.516

Pawluczuk, A., Hall, H., Webster, G., \& Smith, C. (2018). Youth digital participation: Measuring social impact. Journal of Librarianship and Information Science. http://doi.org/10.1177/0961000618769975

Percy-Smith, B., \& Thomas, N. (2009). A handbook of children and young people's participation: Perspectives from theory and practice. London: Routledge. http://doi.org/doi:10.4324/9780203871072

Reynolds, R. (2016). Defining, designing for, and measuring "social constructivist digital literacy" development in learners: A proposed framework. Educational Technology Research and Development, 64(4), 735-762. http://doi.org/10.1007/s11423-015-9423-4

Sapin, K. (2013). Essential skills for youth work practice. London: Sage.

Sawhney, N. (2009). Voices beyond walls. The role of dig- 
ital storytelling for empowering marginalised youth in refugee camps. In Proceedings of the 8th international conference on interaction design and children (pp. 302-305). New YorK, NY: ACM. http://doi.org/ 10.1145/1551788.1551866

Stornaiuolo, A., \& Thomas, E. E. (2017). Disrupting educational inequalities through youth digital activism. Review of Research in Education, 41(1), 337-357.

Van Deursen, A., Helsper, E. J., \& Eynon, R. (2014). Measuring digital skills: From digital skills to tangible outcomes (project report). London: DiSTO Publications. Retrieved from http://www.Ise.ac.uk/media-

Van Laar, E., van Deursen, A. J. A. M., van Dijk, J. A. G. M., \& de Haan, J. (2017). The relation between 21stcentury skills and digital skills: A systematic literature review. Computers in Human Behavior. http:// doi.org/10.1016/j.chb.2017.03.010

Walker, K. (2007). Youth empowerment evaluation learning voice. American Journal of Evaluation, 28(3), 321-326. http://doi.org/10.1177/10982140073063 77

Wilson, C. (2012). Media and information literacy: Pedagogy and possibilities. Comunicar. http://doi.org/10. 3916/C39-2012-02-01

Wilson, G., \& Grant, A. (2017). A digital world for all? Findings from a programme of digital inclusion for vulnerable young people across the UK. Dunfermline: Carnegie United Kingdom Trust. Retrieved from https://d1ssu070pg2v9i.cloudfront.net/pex/ carnegie_uk_trust/2017/10/NotWithoutMe-2.pdf

Youth Link Scotland. (2017). Youth Link Scotland. Retrieved from https://www.youthlinkscotland.org

\section{About the Authors}
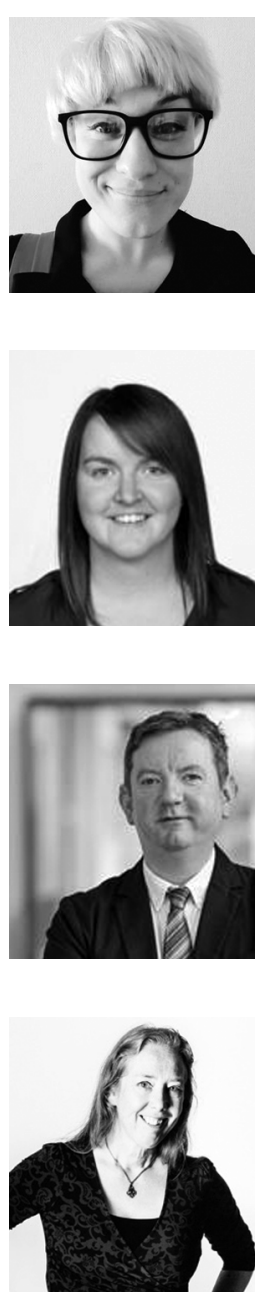

Alicja Pawluczuk is a PhD student and an Associate Lecturer at the School of Computing at Edinburgh Napier University. Alicja's research examines the social impact of digital youth participation in the United Kingdom. She has extensive experience of community-centred digital literacy and digital inclusion workshops design and facilitation both on the national and international level. Alicja research interests include digital youth, digital literacy, community development, and social impact.

Gemma Webster is a Lecturer in the Information Systems Subject Group. Gemma's principle research interests lie in the field of human computer interaction, health care, older adults, community and assistive technologies. She is an experienced multidisciplinary researcher who has worked in a number of different environments and areas including healthcare, nature conservation, community organisations and heritage. A key aspect of all Gemma's research is that it involves 'real-world' environments, problems and partners.

Colin Smith is Senior Lecturer at Edinburgh Napier University. Colin's research examines the relationships between new information and communication technologies (ICTs), strategic innovation and organisational change, particularly in the contexts of e-government and e-democracy.

Hazel Hall (PhD MA BA FRSE FHEA FCLIP) is Professor of Social Informatics within the School of Computing at Edinburgh Napier University. She is also Docent in Information Studies in the Faculty of Social Sciences, Business and Economics at Åbo Akademi, Finland. Hall is active world-wide in Library and Information Science research. For example, she holds (or has held) distinguished external appointments, such Chair of the Research Councils UK Digital Economy Programme Advisory Board and Papers Co-Chair of the ASIST Annual Meeting. 